thing on which all would agree is that methods of teaching, the content of courses and the regulations must all be adjusted at suitable intervals of time in the light of new knowledge and new demands.

NORMAN BOOTH

\section{ROYAL COMMISSION ON AWARDS TO INVENTORS}

$\mathrm{T}$

HE Royal Commission on Awards to Inventors, under the chairmanship of Lord Cohen, which was appointed in 1946, has now submitted a third report containing a general survey of the principles which have guided its decisions and some particulars of the more important claims dealt with up to November 8, 1952.

Since hearings started in February 1947, the Commission has sat in public on 278 days and disposed of 325 cases. Many of the claims have presented features of great complexity and have involved hearings extending over several days. About 255 cases were withdrawn after being referred to the Commission. This large number of withdrawals indicates that the procedure adopted by the Commission for enabling the claimant and the government department concerned to set out their case in writing in the first instance has been useful in clarifying and leading to the settlement of many difficult cases without recourse to a hearing.

The Commission, under its terms of reference, can only deal with those cases referred to it by the Treasury or the government department concerned. To assist the department in determining which cases should be referred, the chairman, at the request of the Treasury, set up an Investigating Committee consisting of two or three members of the Commission who carefully examine all claims submitted to it. This Committee has dealt with about 280 claims. Many of the claims comprised several inventions which had to be considered separately.

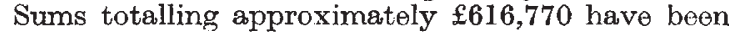
awarded since the Commission began its work. By far the largest number of claims has been on an ex gratia basis-that is, where the claimant has no legal right to payment but relies upon the bounty of the Crown. Under this heading, for example, the Commission has awarded a total of $£ 94,600$ to the inventors of radar installations, including $£ 50,000$ to Sir Robert Watson-Watt. A further series of claims for which a total of $£ 23,300$ was recommended concerned the inventions (generally known as 'degaussing') used on ships to counteract the German magnetic mine. Other claims concerned the 'Fido' project for dispersing fog from airfields, the 'Leigh' light for aircraft used in anti-submarine warfare and the 'Morrison' table shelter for air-raid protection.

The Commission has also dealt with several legal claims based on the use of patents, in these cases acting in lieu of the High Court. One of these inventions concerned stabilizing gear for reducing the rolling of ships, and the Commission awarded the claimants $£ 27,500$.

The Commission has continued the shortened procedure for dealing with claims, for this procedure provides a claimant with a more expeditious and less expensive means of bringing his claim to a hearing.

Although there is still a considerable number of claims outstanding, which the Commission will deal with as and when it is ready for hearing, it can now be claimed that the major part of the task allotted to the Commission has been accomplished.

\section{COMMONWEALTH FUND}

\author{
ANNUAL REPORT FOR 1951-52
}

$\mathrm{T}$ HE thirty-fourth annual report of the Commonwealth Fund*, founded on October 17, 1918, by Mr. Stephen V. Harkness (whose residence, Harkness House, New York, was bequeathed to the Fund and is occupied as its headquarters), covers the year ended June 30,1952 . Of the $2 \cdot 7$ million dollars appropriated during the year, 39 per cent was for medical education, 16 per cent for experimental health services, 15 per cent for medical research and 8 per cent for fellowships, including advanced fellowships in medicino and allied fields, particularly for work involving the crossing and re-crossing of interdisciplinary frontiers, and thirty-one British fellowships and nine Salzburg fellowships. The report lists the thirty research projects currently aided by the Fund; and, of the nine which were new or renewed during the year, six relate to integrative processes in man or to crucial factors in the adjustment of man to this environment.

The major interest of the report, however, lies in its account of the experimental work in medical education and in health services supported by the Fund and of the ideas which are guiding these experiments. In medical education, the experiments turn on the assumption, still to be verified, that medical teaching organized around the student's need to learn and the patient's need for care, will prepare students to meet the responsibilities of medicine as a social institution more effectively than medical teaching organized around the preoccupation of teachers with what they as specialists think they ought to teach. To the five-year grant made in 1950 for the reorganization of the curriculum at the Western Reserve School of Medicine, a further grant of 276,428 dollars has been added. This will facilitate a reorganization in which the initial two phases will occupy about two and a half years ; first, the student is oriented to medicine and to the patient, presenting the fundamental principles of man's structure, function, growth, behaviour, and relation to his environment; and then, during the second phase, dealing with disease (by general principles and afterwards by organ and site), the teaching will be done by interdepartmental teams on which each man will teach what he is best fitted for ; the third and final phase of the reorganization will take a further eighteen months and will deal with the care of sick people.

The second group of experiments embraces grants to the University of Colorado School of Medicine and to the Cornell University Medical College for studies relating to teaching and learning by contact with patients in the clinical years of the medical course, conducted in a new kind of elinic which will put a premium on continuity and comprehensiveness in medical care. If the experiments succeed, they should assist in providing answers to some of the outstanding questions regarding the relation of generalized to specialized medicine, the responsibility for insight into the patient's total problem and the like. The Fund has also made a new grant for the support of the "family general practice" clinic begun at the University of Tennessee College of Medicine in the autumn of $195 \mathrm{l}$, and one of 200,000 dollars for the expenses of a working-party for three years to devise

* Commonwealth Fund. Thirty-fourth Annual Report for the Year ending June 30,1952 . Pp. xiif +42 . (New York: Commonwealth Fund, 1952.) 